\title{
SURFACE STRATEGY TAXONOMY ON THE EFL STUDENTS' COMPOSITION: A STUDY OF ERROR ANALYSIS
}

\author{
Suhono ${ }^{1}$ \\ Institut Agama Islam Ma'arif NU Metro Lampung \\ Suhono120708@gmail.com
}

\begin{abstract}
This study deals with error analysis on composition written by EFL Students IAIM NU Metro. It aims at developing further analyzing of error analysis in second language learners. For this purpose, an empirical study was conducted, using Indonesian students learning English as the subject of research. To achieve this purpose, the researcher explored the type of grammatical errors made by students at different grade semesters: the second, the sixth, and the eighth. More specifically, this study was an attempt to describe the type of grammatical error which frequently exist in written composition, to describe frequency grammatical error among the grade semesters, and to describe the sources of errors. Students' writings were analyzed based on surface strategy taxonomy theory. The results of this research revealed that 268 sentences indicated errors. In all semesters, types of omission error was the highest one 131 (48.9\%) sentences. Furthermore, grammatical error in the second semester was the highest one $124(46.8 \%)$ sentences. The sources of errors of this research were mother-tongue influence (Interlingual errors). It was influenced by the native language which interferes with target language learning. The second was Intralingual errors, caused by the target
\end{abstract}

\section{${ }^{1}$ DosenTetap Prodi PendidikanBahasaInggris}

(PBI)

FakultasTarbiyahInstitut Agama Islam Ma'arif (IAIM NU) Metro Lampung. 
itself like, misanalysis (wrong hypothesis), incomplete rule application.

Keywords: Surface Strategy Taxonomy, Error Analysis, IAIM NU Metro.

\section{DISCUSSION}

Second Language learners often have difficulty and thus do error when using the language. Many scholars have been investigating error for many years ago. Errors were considered as a problem that should be decreased as soon as possible. Recently, Anyhow, errors seem as a utensil that assist in language learning process, especially as a foreign language. Learning error analysis provide an opportunity to us better insight into the process of learning. Hence, error are now considered as a very important tool for diagnostic in language teaching. Here the researcher explains background of the study, problem statement, and Research Method.

\section{A. INTRODUCTION}

In modern era, science is needed to human being in order to be useful people. So, we as the people always hope to our god to be the better people to face some problem in the world. We learn many kinds of science to get much knowledge to be better in our live. We are demanded finding knowledge from many ways such as from our teachers who have more knowledge, as the holly Quran An - Nahl: 43 says:

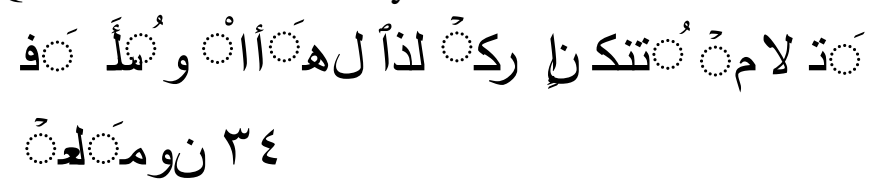

"So ask the followers (have a good knowledge) if you don't know anything" 
Learning English language is one of science that should be learnt to all the people. English becomes very important and useful for us. The existence of English becomes an international language of daily conversation which is spoken by many people in each country. Since its position as International language, English plays important role in International relations such as in science, economic, diplomatic, commerce, politic, etc. As one of developing countries, Indonesia has to keep abreast the world's scientific and technological development. English has been promoted to all levels of education in Indonesia for many years. Furthermore, the Indonesian government has included English as one of the compulsory subjects to be taught in each level of education such as elementary school, junior high school, senior high school and university. It gives the students to engage their English learning process in each different level from the lowest to the highest level at elementary until university. It means that Indonesian government is going to effort the realization of education national goal and to develop the intelligence of the student.

The students are mostly difficult in learning English. The researcher finds some errors done by the students of IAIM NU Metro. It means that many graduate students from junior high school or senior high schools are still lack of understanding in writing, although they have studied for more than six years. Some students of IAIM NU Metro have the problems in writing paragraph. They construct English sentences according to the Indonesian rules.

So far, error analysis have been studied as second foreign language which involve the second language learners on the different background of country, for instance, English foreign language learner in Philippines (Lasaten, 2014). He studied error in the English writings 
of teacher education student. The second was English foreign language learner in Thailand (Watcharapunyawong and Usaha, 2013). They focused on investigating writing error in different text which is caused by interference of Thai Language. The third was

English foreign language learner in Saudi Arabia (AlMohanna, 2014). He focused on identifying the types of error in indefinite articles made by EFL students Saudi

University. The fourth was English foreign language learner in Iran (Al Khotaba, 2013). He focused on the speakers' error in English preposition and adverb articles.

In the scope of error analysis, especially the researchers in Indonesia, studying error analysis on the different students' grade semester are rarely done by the researchers. Hence, the purposes of this research develop

further analyzing of error analysis in second language learners of English Study Program at different grade semester of IAIM NU Metro.

\section{B. Problem of The Study}

The problems in this study are as follows.

a. What are the types of errors in written production made by EFL students of IAIM NU Metro?

b. What are the types of errors which frequently exist in written production?

c. Which one does it have the most error among the grade semester?

d. What are the sources of those errors?

\section{Research Method}

This research used descriptive qualitative. The subject of this research consist of grade semester two, six, and eight that consist of $12 \mathrm{EFL}$ students in each grade semesters. The total number of this research was 36 
students of IAIM NU Metro. The subject of this research contains error from the students' writing composition. In technique of collecting data, the research used elicitation technique and documentation. In elicitation technique the researcher gave students a piece of paper each and gave two topics about students' opinion on learning English from internet and from teacher, which one is more effective, then second topic was about students' opinion campus life. The researcher limited the time to do the elicitation and supervised the students during the elicitation in order that they did by their own work. Having all the data been collected, the writer then analyzed them. In Documentation the researcher used to collect the supporting data. It was used to get the information of the institute as the research subject, the information about total number of English department students and the complete name of the sample of this research

\section{Theoretical Background}

In learning foreign language, language learners begin learning a language from their mother tongue. The learners may encounter mistake or error much of the time. The difficulties of ongoing process in acquiring learning cause second language learners make errors. Making error can be caused by first negative transfer since the structure of first language is unlike from that of target language in learning process.It can be ensured as an integral part of language acquisition that is not avoidable. Thus, the phenomenon of error has been giving more attention for researchers in second language acquisition.

In a traditional second language acquisition, the learners are considered as the linguistic phenomena from the rules of language and standard usages, reflecting learners' deficiency in language competence. Many teachers merely 
correct individual errors as they occur, with little effort to see patterns of errors or to look for the causes in anything other than learner ignorance. Actually, Error analysis had a long history as far as second language learning is involved. The idea of the error as an effective to be avoided has been especially supported by behaviorism, being considered an obstacle to language learning. ${ }^{2}$ The theory from behaviorist to be the issue of second language learning, proposed that the learning process was mainly a question of acquiring of new set language habits. Because of behaviorists viewed error as a symptom not effective and evidence of failure in teaching learning process, consequently, error was regarded as being the result of the perseverance of existing first language habits in the new language ${ }^{3}$. Behaviorist believed that when ineffective teaching learning occurs, intensive drilling and over-teaching were mainly to correct form. Nevertheless, error that was not described in this way was trivialized. It means that the result of error dealt with the same technique of further over-learning and drilling.

Contrastive analysis lay in behaviorist account of language learning, regarded language learning as a mechanical process of habit formation. ${ }^{4} \mathrm{CA}$ grasped that the second language would be instilled by the first language. In this case language is taken from habit and learning process as the establishment of the new habit. In consequence, in the case of interference or negative transfer, certain elements or structures of the first language doesn't have conforming counterpart in target language. Error analyses, which are signifying in language practitioners, has made a substantial

\footnotetext{
${ }^{2}$ Lopez, The Error in The Second Language Acquisition, CS Canada, Universidad de Malaga, Vol. 3, No. 3, 1999., p.1.

${ }^{3}$ VacideErdogan, Contribution of Error Analysis to Foreign Language, Mersin University Journal of the Faculty, Mersin University, Vol. 1, 2005, p. 2.

${ }^{4}$ Rood Ellis \& Gary Barkhuizen, Analysis Learner Language, Oxford University Press, New York, 2005, p. 23.
} 
contribution to the theoretical consciousness-raising of linguistic. ${ }^{5}$ It means that it attempt to validate the prediction of contrastive analysis by systematically gathering and analyzing the language learner production. Finally, in the 1970's error analysis became recognized and gets more considerable attention of applied linguistic.

Saville-Troike says error analysis is the first approach to the study of SLA which includes an internal focus on learners' creative ability to construct language. ${ }^{6}$ Because through focus on evidence of learners' error, becomes more comprehensive to understand of underlying process of second language acquisition. In other word, it is as a signal that learners do ongoing process in target language into langue learner's mind. As Ellis says that EA reflects gaps in learner's knowledge ${ }^{7}$. The learner cannot insightful learn in language process without first consistently doing errors. Hence, it includes naturally on language learner errors come along in the process of language learning.

\section{Error and Mistake}

Error and mistake are quite different. Everybody knows that when people communicate with the others, unconsciously, they will do several errors in language learning process. It the real condition that makes error is unavoidable part of learning. People can not learn language without committing error. The error may actually be necessary part of learning language process. Brown suggests an error as noticeable deviation from the adult grammar of a native speaker, reflecting the inter language competence of

\footnotetext{
${ }^{5}$ Dulay, Burt \&Krashen, Language Two, Oxford University Press, New York, 1982, p. 142.

${ }^{6}$ Muriel Saville-Troike, op.cit. p. 38.

${ }^{7}$ Rood Ellis,Second Language Acquisition, Oxford University Press, New York, 1997, p. 17
} 
the learner ${ }^{8}$. Errors are systematic which are characteristic of the learner's linguistic system at a given stage of learning. The key point is that the learner is using a definite system of language at every point in his development, although it is not that of the second language. The learner 's errors are evidence of this system and are themselves systematic. Errors arise due to the imperfect competence in the target language.

Brown asserts that mistake refers to performance error that is either a random guess or a slip in that is failure to utilize a known system correctly. ${ }^{9}$ It is deflection due to performance factors that undergone by the learners such as memory limitation, tiredness, emotional strain, etc for instance mistake in the sequence of agreement and tenses in sentences, spelling and pronunciation. They are typically random and readily corrected by the learner himself when his attention is drawn to them. Mistakes can only be corrected by their agent if their deviance is pointed out to him or her. So, it can be concluded that mistake is a performance of error that is the slips of the tongue; it is not the result of the lack of competence

\section{Surface Strategy Taxonomy}

James proposes that the learners' erroneous version is different from the presumed target version. This highlights the ways surface structures are altered ${ }^{10}$. The students may omit necessary items or add unnecessary one, they may misform the items or disorder them. Errors can be classified into four types: omission, addition, misformation and misording. Then, James adds blend error as the category of surface strategy taxonomy.

a) Omission

\footnotetext{
${ }^{8}$ H. Douglas Brown, Principles of Language Learning and Teaching, Englewood Cliffs, Prentice-Hall Regents, 2007, p.258.

${ }^{9}$ H. Douglas Brown, op.cit. p. 257

${ }^{10}$ Carl James, op.cit. p.106.
} 
When a learner is leaving off necessary items that must emerge in a well-performed utterance, that learner is doing omission error ${ }^{11}$. As an example we know that morpheme or words can be distinguished into two classes: content word (e.g. noun, verb, adjective, and adverb) and grammatical word such as noun and verb inflection (-s, -ed, -ing), the article (a, an, the), verb auxiliaries (is, am,are, will, can, must etc), preposition (in, on, at, etc). language learners generally omit grammatical morpheme much more frequently than content word such as in John new student, He speak English well, and she eating dinner.

b) Addition

Addition errors, which are the contrary of omission, are characterized by the presence of items that should otherwise not appear in a well-performed utterance. ${ }^{12}$ Generally, it occurs in second language acquisition of the leaner. Regularizations, double markings, and simple addition are kind of addition error which have been examined in the speech of both first language and second language leaner.

c) Misformation

Misformation,are the error that characterized by the use if the wrong from of a structure or morpheme. ${ }^{13}$ there are three type of misformation namely, regularization error (neglecting exception and dissemination rules to domain where the learner don't use the rules transformation of verb and countable or uncountable noun, for instancefalled, Runned, womans, phenomenons, critorions, etc) archi-form (selection of one member of a class of form to represent other on the class,

\footnotetext{
${ }^{11}$ Ibid, p. 154 .

${ }^{12}$ Ibid, p. 156.

${ }^{13}$ Carl James, op.cit. p.108.
} 
d) Misordering

Misording errors are characterized by the incorrect placement of a morpheme in an utterance. They come about systematically for both first and second language learning in construction that already been acquired. For instance:He is all the time late all the time is misordered.

e) Blending

James assertsblend error is sometimes called the contamination or cross-association or hybridization error. ${ }^{14}$ It is also called as combining or mixing (a substance) with another so that the component parts undistinguishable from one to the other. The characteristic of blending is when two alternative grammatical forms combine each other to produce ungrammatical blend. For example; According to Erica and in Erica's opinion.

\section{Discussion and Finding}

The researcher describes the data of erroneous sentences made by Students of IAIM NU Metro. The data are taken from the result of the written production which consists of the second, the sixth, and the eighth semester. The data analysis is based on the classification of error of surface strategy taxonomy. This data analysis involve describing types of grammatical error, describing types of grammatical errors which are frequently exist in written production, describing the most error among students at difference semesters, and the source of errors.

\section{Types of Error Based on Surface Strategy Taxonomy}

${ }^{14}$ Carl James, op.cit. p.111. 
Omission, especially which of first language, is one of characteristic of making errors.After analyzing all data, the researcher found 131 omission errors.

a. Omission of "-s" Noun Inflection in plural form.

In the plural form we can add "-s/-es" to singular noun.

It indicates that singular is different with plural form. After analyzing the data, the researcher found an omission of $-\mathrm{s}$ /es noun inflection in plural form: Omission of " s/es" noun inflection in plural form after determiner

: Although many student learn English from internet

(UAS/2/1)

: Although many students learn English from internet

: The teacher give some subject

(UAS /2/9)

: The teacher gives some subjects

b. Omission of To be

To be consist of am, is, are, am, was, were, be, being, been, etc. In this case, the students omit to be in the sentence. Here are the examples of error made by Students of IAIM NU Metro:

Omission of to be "is"

: Internet $\varnothing$ very important

(SPR8/1)

: Internet is very important

: Internet $\varnothing$ very effective for many people

(SPR8/3)

: Internet is very effective for many people

: Everyone $\emptyset$ very like to open internet

(SPR8/4): Everyone is very like to open internet

c. Omission of to be "is" in passive form

$(\mathrm{HF} / 8 / 1)$

: They can search the material that $\varnothing$ given from teachers in the school

: They can search the material that are given from teachers in the school 
From the sentence above, the students omit to be "are". When the students use passive form, they should add to be are as indicating of passive form. Because when the students to express person affected by the action of a verb, student should add to be (am, are, is, etc) + Verb 3.

d. Omission of Auxiliary

The function of auxiliary is to help other verbs to express the meaning in the sentence. The Auxiliary include: do, does, did, etc. Here are the examples of error made by students in written production: Omission of "do" auxiliary in Negation : because IØ not know about English

(UAS /2/11)

: because Ido not know about English

In the sentences above, grammatical function " $d o$ "auxiliary are added to the predicate to create negative statement or question form. Unfortunately, the students neglect " $d o$ "auxiliary in negative form. They don't add " $d o$ " in negative form.

Addition, especially presence of item which should not appear in a well-performed utterance, is a characteristic of making error. The appearance of addition error is the outcome of all-too-faithful use of a specific one rules.after analyzing all data, a total of 43 errors were identified in addition errors

a) Addition "-s/-es" noun inflection

: IAIM NU Metro has a students

$(\mathrm{LE} / 8 / 3)$

: IAIM NU Metro has a student

In this case, the students are not suitable with the sense of singular subject of the sentence. Because when the word article "a/" put in the sentence, noun should be singular form. The problem of the first sentence above is presence of item "-s" in the end of "students" noun of this sentences.It indicates imperfection the grammar. So, the word "students" should be changed "student". 
b) Addition ofof "-ing" Verb after modal

: we can understanding one of study of teacher or lecturer (YES/2/7)

: we can understand one of study of teacher or lecturer

: we can learning from internet and teacher

(YES/2/10)

: we can learn from internet and teacher

: we can learning both of them

(YES/2/14)

: we can learn both of them

From the pattern of the sentences above, the student add the '-ing' ending of the word after modal. As we know that, Modal is followed by infinitive verb. So, it should be changed into infinitive verb

c) Addition of to be

There are different rules to use structure or grammar of sentence between Indonesian and English language, such as the rules of using to be in English grammar. Because in English grammar there are to be, such am, are, is, was, were, etc. After analyzing data, the researcher found error in addition to be, for instance:

Addition of to be "is"

(UHR8/1)

: Because the teacher can transfer material to students is directly

: Because the teacher can transfer material to students directly

From the pattern of the sentences above, the students failed to operate to be, conversely they add "is" to be which must not appear in the sentence.

Misformation, especially the use of the wrong form of the morpheme or structure, is a characteristic of making error. In this case, the students put a word, nonetheless it is faulty. When the learners' knowledge of first language do free alternation of various members of a class with each other, 
that learners do alternating form. A total of 68 errors were identified in Misformation errors.

a. Misformation of Verb Posses "has" and :have"

: The lecturer absolutely have some programs of teaching of the class.

: The lecturer absolutely has some programs of teaching of the class.

: Although it have more comprehensive source $(\mathrm{AF} / 2 / 4)$

: Although it has more comprehensive source

: Student have some social activities through this organization $(\mathrm{AF} / 2 / 10)$

: Student has some social activities through this organization

From the sentences above, the student put wrong verb posses "has" and "have". Most of the students failed to use verb possess, because verb posses "has" is used by the third person singular ; he, she, it.while verb posses "have" is used by I, you, they, we.

b. Misformation of to be

In English grammar, to be consist of am, is, are, am, was, were, be, being, been, etc. After analyzing data, the researcher found error in misformation of to be, for instance

Misformation of to be "is" instead of "are"

: Because friends and lecturers is friendly

(UAS /2/7)

: Because friends and lecturers are friendly Misformation of to be "is" instead of "are"

: Because friends and lecturers is friendly /2/7)

: Because friends and lecturers are friendly

The sentence above, the learner put "is" to be, nonetheless it is inaccurate. Because plural noun must be 
followed by plural verb (are). So, "is" to be should be changed "are" to make suitability between plural nouns and plural verb in the sentence.

c. Misformation of Quantifier

Misformation of determiner of uncountable for countable

: We need much places to study out of the class

$(\mathrm{AAK} / 2 / 2)$

: We need many places to study out of the class

: We still need much organization

(AAK/2/4)

: We still need money organizations

In grammatical function, quantifier (many, much, a lot of, etc.) is used to know the quantity of noun, unfortunately the student failed to use it. The word "many" should be changed "much" to make suitability with uncountable noun: "information", because "many" is used to countable noun, while "much" is used to uncountable noun. Then in the second sentence, word "much" should be changed "many" to make suitability with countable noun: "places".

Misordering errors which refer to incorrect placement either of a morpheme or group of morphemes in an utterance are the characteristic of making error.

questions A total of 11 errors were identified in

Misordering errors:

a. Misordering of Adjective Phrase

: The teacher can make student smart

(IW/8/1)

: The teacher can make smart student

: Internet make student lazy

(IW/8/2)

: Internet make lazy student

The examples of sentence pattern of above, the learner put incorrect adjective and noun. When we want to 
describe a noun, we should put on the position of adjective before noun. In English grammar it call adjective phrase which has function to modify noun. So the sentences above should be "lazy student" and "smart student"

Blend error is sometimes called the contamination or cross-association or hybridization error. It is also called as combining or mixing (a substance) with another so that the component parts undistinguishable from one to the other.

a. Misspelling

: we search nowledge

(YES/2/16

: we search knowldeg

: we can get nowledge

(YES/2/17

: we can get knowledge

The problem of the sentence above, the learner writes wrong spelling word English. The learner write "nowledge" for the word "knoledge", the learner's errors are caused by the limitation of students' vocabulary in English.

\section{The Types of Grammatical Error which Frequently Exist in Written Production}

After analyzing all data the data the researcher found the types and frequent of errors in written production made by students of IAIM NU Metro. A total of errors 266 were identified in all semesters. Here are the types of errors which frequently exist in written production.

\section{The Summary Types of Error}

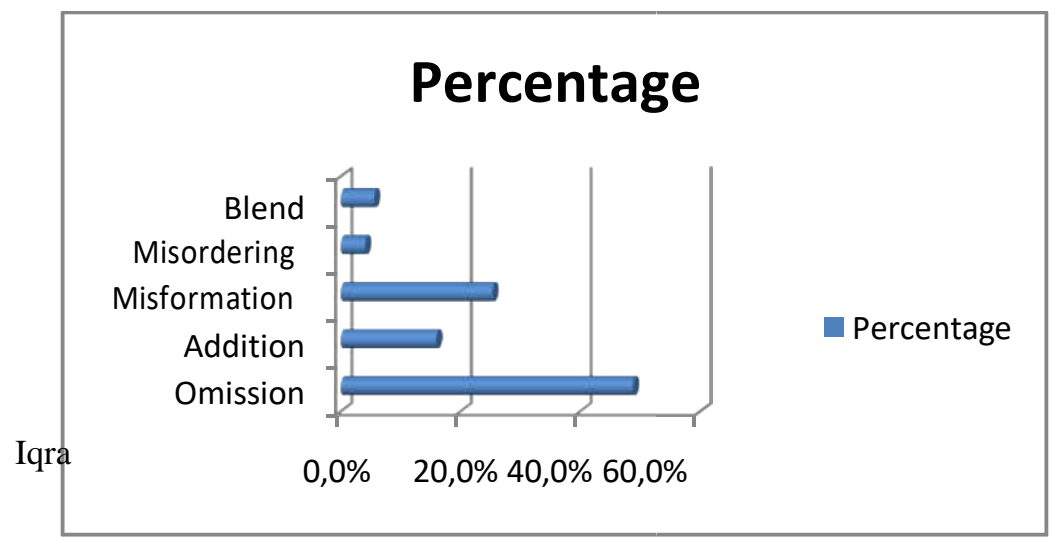


Type omission is the highest error in written production made by students of IAIM NU Metro. It is one of the types of error which frequently exist in written production, because the highest percentage of omission errors is 131 sentences. These errors consist of three semesters.

These omissions errors can be classified into 7 types of errors.

From some types omission of error, omission of "-s/-es" noun inflection is the most frequent one, that is $51(38.9 \%)$ sentences. Omission of to be is the second rank 44 (33.6\%)sentences. The third rank is Omission of "-s/es" verb inflection: 18 (13.7\%)sentences. The fourth rank is Omission of Verb 9 (6.9\%) sentences and Auxiliary 6 (4.6\%) sentences. Omission of preposition is $2(1.5 \%)$ and Omission of subject $1(0.8 \%)$ sentences is in the last rank.

The second primary error is misformation error. The researcher found 68 sentences containing errors. These errors consist of three students' semesters. These misoformation errors can be classified into 14 types of errors. Here are some classifications of Misformation errors: Comparative in degree of comparison is the most frequent one, 13 (19.1\%) sentences. Misformation of Determiner of Quantifier is $10(14.7 \%)$ sentences. The third rank is misformation of verb, $9(13.2 \%)$ sentences. The forth rank is Misformation of to be $7(10.3 \%)$. Misformation of verb) posses $6(8.8 \%)$ is fifth rank, then Noun instead of verb $5(7.4 \%)$. The seventh rank is misformation of 
pronoun, $4(5.9 \%)$ sentences. The eight rank is misformation of Auxiliary, 3 (4.4\%) sentences. Afterward, misformation of verb instead of noun, 2 (2.9\%) sentences.. The occurrences of misformation of preposition $1(1.4 \%)$ sentences, adjective instead of noun, $1(1.4 \%)$ sentences, article instead of subject, and noun instead of adjective are successive rank.

Addition is in the third rank of error. The total number of addition error in on three semesters are 43 sentences. These addition errors can be classified into 7 types of errors. Addition of "-ing" verb inflection is the highest one, that is $13(30.2 \%)$ sentences. Addition of verb "-ing" after modal is $11(25.6 \%)$ sentences. Addition of to be is in the third rank $6(14 \%)$ sentences. Addition of verb (double verb) 5 (11.6) and Addition of Preposition 5 (11.6) are in the forth rank. The Fifth rank is addition of modal verb, $2(4.7 \%)$ sentences. The seventh rank is addition of subject, 1 (2.3\%).

The fourth major error is blend errors. The researcher found 15 sentences indicating errors. These consist of three semesters. These misformation errors can be classified into 2 types of errors. Misspelling of word is in the highest rank, 14 (93.3\%) sentences. The second rank is wrong choice of verb 1 (6.7\%) sentences.

The last is misordering error. The total numbers of misordering error in these semesters are 11 sentences. These misordering errors can be classified into 2 types of errors. Misordering of sentence pattern is the highest one, $8(72.7 \%)$ sentences. The second rank is misordering of adjective phrase 3 (27.3\%) sentences. 


\section{The Grammatical Error Mostly Occur among the Grade Semesters of IAIM NU Metro.}

This part the researcher delineates the result of percentage grammatical error among three semesters:

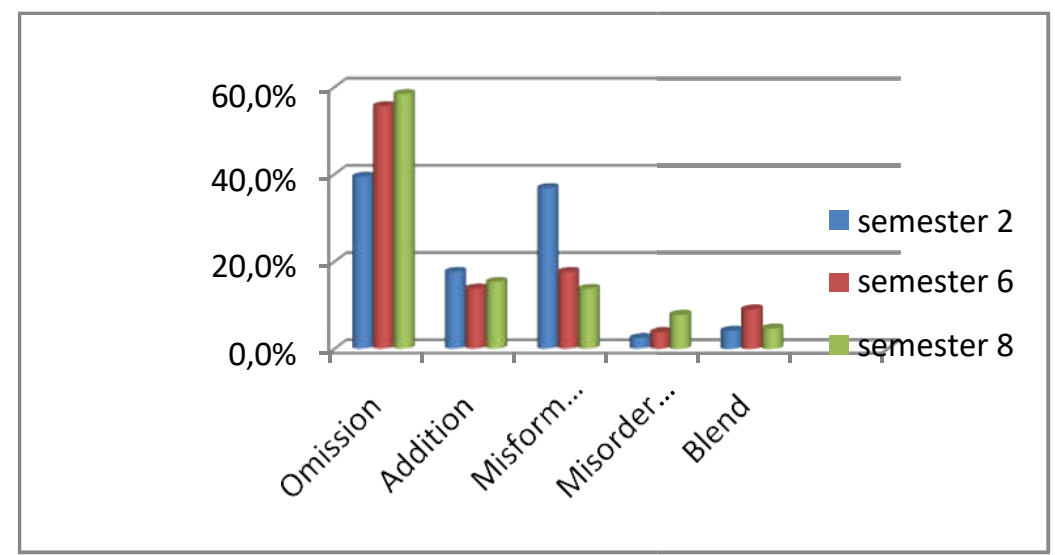

After analyzing all data, the researcher found 268 errors. These errors consist of $124(46.8 \%)$ in the second semester, $76(28.7 \%)$ in the sixth semester and $65(24.5 \%)$ in the eighth semester. The total number of types of errors in each level is quite different. Omission error is the highest one 131 (48.9\%) sentences, nevertheless these errors are quite different in each grade semester. Table 2 shows that how the percentage of type errors in the grade semester of 2,5 , and 8 are very different. In omission of error, the total of students' omission error the sixth semester is 44 (55.7\%)sentences, nonetheless omission error in semester two is higher 49 (39.5\%) sentences than the sixth semester, and semester eight is the lowest one $38(58.5 \%)$ sentences.

Missformation error is in the second rank in all type of errors that is $68(25.6 \%)$ sentences. 
Nevertheless these errors are very different in each grade semester. In missformation error, the total number of students' misformation errors in semester six is $14(17.7 \%)$ sentences, however missformation in semester two is the highest one 45 (36.9\%), and the eighth semester is the lowest one $9(13.8 \%)$.

Addition errors are in the third rank in all types of errors: 43 (16\%) sentences, nevertheless these errors are quite different in each grade semesters. In addition error, the total number of students' addition errors in semester eight is 10 (15.4\%) sentences. It is higher than error in semester six that is $11(13.9 \%)$ sentences, conversely semester two is the highest one $22(17.7 \%)$ sentences.

The third rank is blend error. The researcher found $15(15 \%)$ sentences indicating errors, nonetheless these errors are quite different in each the grade semesters. The total number of students' blend errors at the eighth semester is $3(4.6 \%)$ sentences, it is lower than blend errors at the second semester 5 (4\%) sentences, meanwhile the sixth semester is the highest one 7 (8.9\%) sentences.

Misordering error is in the last rank in all type of errors that is $11(4.1 \%)$ sentences; nonetheless these errors are quite different in each grade semesters. The total number of misordering errors at the second semesters is 3 (2.5) sentences. It the same as the sixth semester, 3 (3.8\%) sentences. Conversely the eighth semester is the highest one $5(7.7 \%)$ sentences.

\section{The Sources of Errors}

In identifying error, the researcher must know why they make errors. As we know that the students begin learning a language from their mother tongue, 
Javanese language (L1), the second language, Indonesian Language (L2), and finally the foreign language, English (L3).

Most of the students speak Javanese at home. When they are at school, they speak Indonesia. They hardly speak English, except when they are having English Lesson. They sometimes do difficulties in aspect grammar. Anyhow, it is their strategy to accomplish the target language they learn. Dulay, Burt and Krashen (1982) state that there are some major sources that cause the learner's error, they are: inter lingual error, intra lingual error and context of learning. After the researcher analyzes the data, she finds two dominant sources of errors: intra lingual error and inter lingual error.

1. Interlingual Transfer

According to Richard (1974: 173), inter lingual error is caused by the interference of the learner's mother tongue, they usually transfer the system of their mother tongue into foreign language.It means that, language learners use the structure of first language in target language.

(1) : Internet makesstudent lazy

(IW/8/2)

: Internet makes lazy student

The sentence is the transfer from L1(Indonesian), for example in Indonesian, "Internetdapatmembuatsiswabodoh/Inter net makes student lazy". The error of the sentence is that the student miss placement between adjective and noun. It should be "Internet makes lazy student"..

(2) : Internet make student lazy

$(\mathrm{IW} / 8 / 2)$

: Internet make lazy student 
In the sentence above, the student put incorrect adjective and noun. When describing a noun, we should put on the position adjective before noun. Error caused by direct translation of Indonesian into English. It often occurs because the student tries to apply Indonesian rules into English one.

2. Intra lingual Transfer

Intra lingual transfer refers to items produced by the learner who does not reflect the structure of mother tongue but generalization of the target language. It is caused by negative transfer between the elements in the target language itself. If the learners have acquired the new system, more and more intra lingual transfer is manifested. Negative intra lingual transfer can be illustrated in these utterances.

For example:

(1) : That why a university is consist of many buildings $(\mathrm{AF} / 2 / 8)$

: That why a university consist of many buildings

The sentence above is error in the use of grammar. It caused by the lacking of the students knowledge in using "to be". They often apply "to be" after subject in their sentences. In

English sentence pattern, if the sentence has a full verb it can not take "to be" after subject.

(2) : Although it have more comprehensive source $(\mathrm{AF} / 2 / 4)$

: Although it has more comprehensive source

In the sentence, the students are more familiar in verb posses "have". So he used verb posses "have" in all of their sentences to show 
possession, regardless the kind of the sentences whether they are plural or singular subject..

\section{Conclusion}

Based on the finding of the analysis the research finds errors.. The researcher inspects the analysis of the erroneous sentences in the different grade semester: two, six and eight, as a result the researcher found total 268 containing errors; here are the sum-up of the research problem as follows:

\section{The Type of Grammatical Error}

The result of type or error in this research can be classified into five categories; omission, addition, misformation, misordering, and blend errors. After analyzing data, the researcher found 131 (48.9\%) omission errors, 43 (16\%) addition errors, 68 (25.4\%) misformation errors, $11(5.6 \%)$ misordering errors, and 15 (5.6\%) blend errors.

2. Type of Grammatical Error which Frequently Exist in Written Production.

The researcher found that the category of omission error supplies the most dominant error and it is the highest error in written production: 131 (48.9\%). This omission error can be classified into 7 types of errors. The most significant error is type omission of "-s/-es" noun inflection 71 sentences, that is 51 (38.9\%) sentences. Omission of to be is the second rank $44(33.6 \%)$ sentences. The third rank is Omission of "-s/es" verb inflection: 18 (13.7\%)sentences. The fourth rank is Omission of Verb $9(6.9 \%)$ sentences and Auxiliary $6(4.6 \%)$ sentences. Omission of preposition is 2 $(1.5 \%)$ and Omission of subject $1(0.8 \%)$ sentences is in the last rank.

The second major error is misformation. The researcher found 68 sentences containing errors. These errors 
consist of three students' semesters. These misoformation errors can be classified into 14 types of errors. Here are some classifications of Misformation errors: Comparative in degree of comparison is the most frequent one, 13 (19.1\%) sentences. Misformation of Determiner of Quantifier is 10 (14.7\%) sentences. The third rank is misformation of verb, 9 (13.2\%) sentences. The forth rank is Misformation of to be 7 (10.3\%). Misformation of verb) posses $6(8.8 \%)$ is fifth rank, then Noun instead of verb $5(7.4 \%)$. The seventh rank is misformation of pronoun, 4 (5.9\%) sentences. The eight rank is misformation of Auxiliary, 3 (4.4\%) sentences. Afterward, misformation of verb instead of noun, $2(2.9 \%)$ sentences.. The occurrences of misformation of preposition 1 (1.4\%) sentences, adjective instead of noun, 1 (1.4\%) sentences, article instead of subject, and noun instead of adjective are successive rank.

Addition is in the third rank of error. The total number of addition error in on three semesters are 43 sentences. These addition errors can be classified into 7 types of errors. Addition of "-ing" verb inflection is the highest one, that is $13(30.2 \%)$ sentences. Addition of verb "-ing" after modal is $11(25.6 \%)$ sentences. Addition of to be is in the third rank 6 (14\%)sentences. Addition of verb (double verb) 5 (11.6) and Addition of Preposition 5 (11.6) are in the forth rank. The Fifth rank is addition of modal verb, $2(4.7 \%)$ sentences. The seventh rank is addition of subject, $1(2.3 \%)$.

The fourth major error is blend errors. The researcher found 15 sentences indicating errors. These consist of three semesters. These misformation errors can be classified into 2 types of errors. Misspelling of word is in the highest rank, 14 $(93.3 \%)$ sentences. The second rank is wrong choice of verb $1(6.7 \%)$ sentences.

The last is misordering error. The total numbers of misordering error in these semesters are 11 sentences. These misordering errors can be classified into 2 types of errors. 
Misordering of sentence pattern is the highest one, 8 (72.7\%)sentences. The second rank is misordering of adjective phrase $3(27.3 \%)$ sentences.

3. The grammatical error mostly occur among the grade semesters of IAIM NU Metro

After analyzing grammatical errors at the different grade semesters, the researcher found 124 (46.8\%) sentences error at the second semester, $79(28.7 \%)$ sentences error in the sixth semester, and $65(25.5 \%)$ sentences error in the eighth semester, nonetheless total number in each level is quite different. In omission error, the second semester is the highest one, $49(39.5 \%)$ sentences. The second is the sixth semester, $44(55.7 \%)$ sentences, and the third is the eighth semester, 38 (58.5\%).In misformation error, the second semester is the highest one, 45 (36.3\%)sentences. The second is the sixth semester, $14(17.7 \%)$ sentences, and the third is the eighth semester, 9 (13.8\%). In Addition error, the second semester is the highest one, $22(17.7 \%)$ sentences. The second is the sixth semester, $11(13.9 \%)$ sentences, and the third is the eighth semester, $10(15.4 \%)$. In misordering error, the eighth semester is the highest, $5(7.7 \%)$ sentences, the second level is the second and the sixth semester, $3(2.4 \%)$ and 3 (3.8\%) sentences In blend error, the sixth semester is the highest one, $7(8.9 \%)$ sentences, semester two is the second rank, $5(4 \%)$ sentences and the eighth semester is the last rank, $3(4.6 \%)$ sentences.

4. The Sources of Error

After analyzing the data, the source of errors consist of interlingual transfer. It is caused by mother tongue interference. It is considered as the major barrier of learning a second language or foreign language. While Intralingual errors occurs during the learning process of the second language at a stage when the learners have nor really acquired the knowledge. It also dubbed as a developmental 
errors. It was caused by the transition or transformation form one language to another

\section{Suggestion}

After conducting this research, the researcher would like to recommend for the lecturers, the students and other future researchers.

1. To The Lecturer

Lecturers are the model and guide of their students to get successful in English skills. The lectures or teachers should respect the students' error and give guidance to the students in teaching and learning process. They should discuss to their students how to identify and correct their error in English written text. Furthermore they need more technique in teaching writing to give exercises or practices in the classroom or outside from the classroom.

2. To The Students

The students should more focus and practice in learning English, especially in writing. They should have more pay attention and great winning in learning English process. 


\section{BIBLIOGRAPHY}

Al-Mohana, AyedhiDhawi M. "Error In The Usage of the English Definite/Idenfinite Articles Among Saudi University Level Student" dalamJurnal International, Vol.5, No.2 Tahun 2014, p.15.

Al Khotaba, E. "Errors in the Use of Prepositions and Adverbs Particles by Arab ESL Speakers: Performance Analysis

Perspective"dalamInternasionalJurnalKajianLinguistik, Vol. 5 No.1 Tahun 2013. p.1.

Benzigar. M. “The Rural Madurai Undergraduates' English Writings: An Analysis" dalam Journal of English Language and Literature, Vol.1.Issues.4.2013.p.1.

Brown, H. Douglas. 2007. Principles of Language Learning and Teaching. Englewood Cliffs: Prentice-Hall Regents.

Corder, S.Pit.1981.Error Analysis and Interlanguage.London: Oxford University Press.

Crammer, R. (ed.) 1984.Language Structure and Use. USA: Scott, Foresman and Company.

Dulayetl. 1982. Language Two. New York: Oxford University Press.

Ellis, R and Barkhuzien, G. 2005.Analysis Learner Language. New York: Oxford University Press.

Ellis, R. 1997. Second Language Acquisition, New York: Oxford University Press.

Erdogan, V. 2005.Contribution of Error Analysis to Foreign Language Teaching”dalam Journal Linguistik, Vol. 1, Iqra', Vol. 1, No. 2, November 2016 ISSN: 2527-4449 
Fauziati, E. 2009. Reading on Applied Linguistic. Surakarta: RinekaCipta.

Fisiak, J. 1981. Contrastive Linguistics and The Language Teacher. New York: Pergamon Press

Fudeman, K \&Arnoff, M. 2001. What is Morphology. London: Blackwell Publishing.

James, Carl. 1998. Errors in Language Learning and Use: Exploring Error Analysis. London: Longman.

Khojasteh, L \&Kafipour, R.”The Study of Morphological, Syntactic, and Semantic Errors Made by Native Speaker of Persian and English Children LearningEnglish", dalam Journal Linguistik.Vol.3.No1.2014.p.1.

Lasaten, C, Ronald. 2014. "Analysis of Error in the English Writings of Teacher Educations" dalamkajian linguistic, Vol.5, No.3.2014.p.1.

Lopez, MJC, "The Error in The Second Language Acquisition" dalamkajian linguistic, Vol. 3. No.2, 2001.p.2.

Radorf, A. 2004.English Syntax: An Introduction. Cambridge: Cambridge University Press.

Richard, Jack C. 1970. A Non-Contrastive Approach to Error Analysis. San Francisco: Longman.

R.R Jordan. 2003. Academic Writing Course. Longman : England. 
Muriel Saville-Troike. 2006. Introducing Second Language Acquisition. New York: Cambridge University Press.

Wardhugh, R. 1970. The Contrastive Analysis Hypothesis. USA: San Fransisco.

Watcharapunyawong, S \& Usaha, S. "Thai EFL Students'Writing in Different Text Type: The Interference of the First Language" dalam Journal Linguistik,Vol. 6 No1.2013, p.1. 
Iqra', Vol. 1, No. 2, November 2016 ISSN: 2527-4449 